\title{
PENGARUH AUDIT OPRASIONAL TERHADAP PERSEDIAAN BARANG DAGANG PADA USAHA DEPOT JAYA MOTOR KOTA PALOPO
}

\author{
Junaidi*1, Huldi ${ }^{1}$ \\ ${ }^{1}$ Sekolah Tinggi Ilmu Ekonomi Muhammadiyah Palopo \\ *unaidi@stiem.ac.id
}

\begin{abstract}
This study aims to determine whether operational audits influence the adequacy of merchandise inventory. Data used in this study are primary data, namely data sourced from observations and questionnaires conducted at Jaya Motor Depot Business, Palopo City. To test data reliability, validity test and reliability test are used. The statistical analysis used is simple linear regression to test the influence of the dependent and independent variables. The test results obtained by Operational Audit t count of 5.518 and t table of 2.131 indicates that the value of tcount> $t$ table with a significance level of $0.000<0.05$ then $\mathrm{HO}$ is rejected and $\mathrm{H1}$ is accepted. This shows that operational audits have a significant influence on the adequacy of merchandise inventory.

Keywords: Operational Audit, Adequacy of Merchandise Inventory

Abstrak : Penelitian ini bertujuan untuk mengetahui apakah audit operasional berpengaruh terhadap kecukupan persediaan barang dagang.Data yang digunakan dalam penelitian ini merupakan data primer yaitu data yang bersumber dari hasil observasi dan kuesioner yang dilakukan pada Usaha depot Jaya Motor Kota Palopo. Untuk menguji keandalan data maka digunakan uji validitas dan Uji reliabilitas. Analisis statistik yang digunakan yaitu regresi linear sederhana dilakukan untuk menguji pengaruh antara variabel dependen dan independen. Hasil

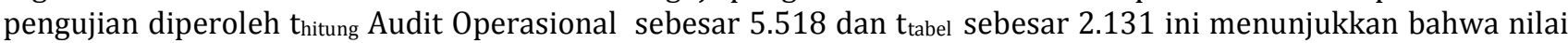
$t_{\text {hitung }}>t_{\text {tabel }}$ dengan tingkat signifikansi $0.000<0.05$ maka H0 ditolak dan H1 diterima. Hal ini menunjukkan bahwa audit operasional memiliki pengaruh yang signifikan terhadap kecukupan persediaan barang dagang.
\end{abstract}

Kata Kunci: Audit Operasional, Kecukupan Persediaan Barang Dagang

\section{PENDAHULUAN}

Semakin berkembangnya perusahaan menuntut pula perkembangan di bidang pemeriksaan. Pemeriksaan yang dilakukan tidak hanya pemeriksaan keuangan tetapi juga pemeriksaan yang menekankan pada penilaian sistematis dan objektif serta berorietasi pada tujuan untuk memperoleh keyakinan tentang keefektifan dan memberikan pendapat atas kewajaran laporan keuangan yang diperiksa. Pimpinan perusahaan memerlukan audit operasional yang menyajikan

informasi mengenai aktivitas operasional perusahaan dan tidak terbatas pada informasi keuangan dan akuntansi saja, suatu organisasi yang dikendalikan dengan efektif terletak pada sikap manajemen. Manajemen adalah pihak yang mengelola serta mengendalikan perusahaan.

Audit operasional merupakan evaluasi atas berbagai kegiatan operasional perusahaan, sedangkan sasarannya adalah untuk menilai apakah pelaksanaan kegiatan operasional telah dilaksanakan secara ekonomis, efektif dan efisien. Apabila belum dilaksanakan seperti sehrusnya, maka auditor akan memberikan rekomendasi atau saran agar pada masa akan datang menjadi lebih baik, yakni dapat memperbaiki kinerja serta pengendalian intern dan mengangkat efisiensi operasional perusahaan.

Setiap perusahaan dalam melaksanakan kegiatan pemasaran,tidak terlepas akan kebutuhan barang dagangan yang menjadi faktor utama dalam menunjang jalannya aktivitas pemasaran perusahaan. Dengan terpenuhinya akan barang tepat pada waktunya, maka kegiatan suatu perusahaan akan dapat berjalan dengan lancar sesuai dengan tujuan yang ingin dicapai. Tanpa adanya persediaan barang dagang, perusahaan akan menghadapi risiko dimana pada suatu waktu tidak dapat memenuhi keinginan dari para pelanggannya.

Berdasarkan pada penelitian pendahuluan yang dilakukan penulis pada tanggal 26, Januari, 2015 di Usaha Depot Jaya Motor diketahui bahwa: Sebagai perusahaan dagang, Usaha Depot Jaya Motor juga menghadapi masalah- 
masalah yang berkaitan dengan penyediaan barang dagang yang diinginkan konsumen. Perusahaan terkadang tidak dapat memenuhi permintaan barang yang diinginkan konsumen sehingga mereka harus menunggu perusahaan untuk memesan barang dari pihak distributor. Namun, sebagai perusahaan yang menjual barang bekas tidaklah mudah untuk mendapatkan barang yang diinginkan konsumen. Perusahaan tersebut harus menunggu barang hasil pelelangan dari Adira Finance.

Masalah lain yaitu, perusahaan sering mengambil barang dagang tanpa mempertimbangkan bahwa persediaan barang yang ada masih banyak sehingga jika dalam satu bulan persediaan yang ada semua tidak terjual maka perusahaan harus menggunakan modal sendiri untuk membayar uang angsuran kepada Adira Finance. Oleh karena itu, maka penulis tertarik untuk meneliti tentang: Pengaruh Audit Operasional Terhadap kecukupan Persediaan Barang Dagang.

\section{KAJIAN PUSTAKA}

\section{Auditing}

Auditing adalah sebuah proses sistematis yang dilakukan oleh seseorang yang memiliki kompetensi dan independensi, mengenali perolehan dan penilaian atau bukti secara objektif yang dilakukan dengan pengumpulan dan penilaian atas bukti-bukti informasi yang dapat dikuantifikasikan dan terkait dengan entitas suatu ekonomi tertentu, berkenaan dengan pernyataan mengenai tindakantindakan dan kejadian-kejadian ekonomi dengan tujuan untuk menentukan tingkat kesesuaian antara pernyataan tersebut dengan kriteria yang telah ditetapkan serta untuk mengkomunikasikan hasil-hasilnya kepada pihak-pihak yang berkepentingan (Purwono,2004:18).

Menurut Halim (2003 :1) untuk mempelajari auditing dan profesi akuntan secara mendalam, perlu kiranya mengetahui definisi audit. Definisi audit yang sangat terkenal adalah definisi yang berasal dari ASOBAC (A Statement Of Basic Auditing Concepts) yang mendefinisikan auditing sebagai berikut:

"Auditing adalah suatu proses sistematis untuk menghimpun dan mengevaluasi buktibukti secara objektif mengenai asersi-asersi tentang berbagai tindakan dan kejadian ekonomi untuk menentukan tingkat kesesuaian antara asersi-asersi tersebut dengan kriteria yang telah ditentukan dan menyampaikan hasilnya kepada para pemakai yang telah berkepentingan".

Menurut Arens, Elder,Beasley (2004:15):

"auditing adalah pengumpulan serta pengevaluasian bukti-bukti atas informasi untuk menentukan dan melaporkan tingkat kesesuaian informasi tersebut dengan kriteriakriteria yang telah ditetapkan. Audit harus dilaksanakan oleh seseorang yang kompeten dan independen".

Agoes (2012:4) mendefinisikan auditing sebagai:

"suatu proses sistematis yang secara objektif mendapatkan dan mengevaluasi bukti mengenai asersi tentang kegiatan-kegiatan dan kejadian-kejadian ekonomi untuk meyakinkan tingkat keterkaitan antara asersi tersebut dan kriteria yang telah ditetapkan dan mengkomunikasikan hasilnya kepada pihakpihak yang berkepentingan".

Dari definisi-definisi tersebut di atas, dapat disimpulkan bahwa audit adalah menyangkut hal-hal 1) Informasi-informasi yang dapat diukur dan kriteria-kriteria yang telah ditetapkan syarat dalam melakukan pemeriksaan adalah informasi yang terpercaya atau dapat dibuktikan kebenarannya dan kriteria standar yang dapat digunakan oleh auditor sebagai pedoman dalam mengevaluasi informasi-informasi tersebut. 2) Entitas ekonomi, ruang lingkup tanggung jawab auditor yang jelas mengenai penerapan entitas ekonomi dan periode waktu diaudit. Entitas ekonomi merupakan satuan legal misalnya perseroan terbatas (PT), Lembaga Pemerintah Persekutuan komenditar (CV), Koperasi, 
Persekutuan Firma ( FA ) atau Perusahaan perseorangan. Kondisi tertentu satuan Perseorangan, tetapi dalam kondisi tertentu satuan juga biasa terbentuk divisi atau departemen periode waktu yang diaudit umumnya satu tahun, tetapi ada juga yang satu bulan, satu kuartal atau beberapa tahun 1) Pengumpulan atau pengevaluasian bukti, adanya bukti - bukti yang memadai baik dari segi jumlah maupun dari segi menu sangat diperlukan untuk menentukan kegiatan audit. Bahan bukti dapat terdiri dari bermacam bentuk yang berbeda termasuk peringatan lisan yang berbeda ( Klien ), komunitas dengan pihak ketiga dan hasil pengamatan auditor 2) Auditor harus independen dan kompeten, independen berarti bebas dari pengaruh - pengaruh hingga batas batas tertentu. Sedangkan kompeten berarti auditor harus mempunyai pengetahuan dan pengalaman yang cukup agar dapat memahami kriteria yang dipergunakan. 3) Pelaporan hasil audit harus mampu memberikan informasi mengenai kesesuaian informasi yang diperiksa dengan kriteria yang telah ditetapkan.

Jenis - jenis Audit

Menurut Boynton, Jonhson, Kell ( 2003 : 490 ) ada tiga jenis audit a) Pelaporan Keuangan ( Financial Audit ) Audit Pelaporan Keuangan merupakan proses yang mencakup memperoleh dan menilai bukti tentang laporan keuangan suatu entitas untuk tujuan menyatakan pendapat apakah informasi keuangan disajikan sesuai kriteria yang ditetapkan. b) Audit Operasional ( Performance Audit) Audit operasional adalah proses mencakup, memperoleh, dan menilai bukti tentang aktivitas operasi suatu entitas berkenaan dengan tujuan khusus yang sering berkaitan baik penilaian kinerja maupun pengambilan keputusan manajemen. Umumnya, pada saat selesainya audit operasional auditor akan memberikan sejumlah saran kepada para manajemen untuk memperbaiki operasional perusahaan. Dalam operasional tujuan dilakukan tidak terbatas pada masalah masalah akuntansi, tetapi juga meliputi evaluasi terhadap struktur organisasi pemanfaatan komputer, metode produksi, pemasaran dan bidang - bidang lain sesuai dengan keahlian auditor. c) Audit ketaatan (Compliance Audit ) Audit Ketaatan merupakan proses yang menilai bukti untuk menentukan apakah aktivitas keuangan dalam operasi tertentu dari suatu entitas sesuai dengan kondisi yang ditetapkan dalam peraturan dan kebijakan. Audit ketaatan bertujuan untuk mempertimbangkan apakah auditor atau klien telah mengikuti aturan tertentu yang telah ditetapkan pihak yang memiliki orientasi lebih tinggi. Hasil audit ketaatan biasanya tidak dilaporkan kepada pihak luar tetapi kepada pihak tertentu yang paling berkepentingan atas organisasi adalah pihak yang paling berkepentingan atas terpenuhinya prosedur dan aturan yang telah ditetapkan.

\section{Audit Operasional}

Audit operasional seringkali diartikan sama dengan audit manajemen. Pengertian sederhana dari audit manajemen adalan investigasi dari suatu organisasi dalam semua aspek kegiatan manajemen dari yang paling tinggi sampai kebawah dan pembuatan laporan audit mengeni efektivitasnya atau dari segi probilitas dan efisiensi kegiatan bisnisnya sedangkan pengertian sederhana dari audit operasional adalah uraian efektivitas perusahaan yang sistematis dalam hubungannya dengan tujuan untuk melihat, mengidentifikasi peluang perbaikan, atau mengembangkan rekomendasi untuk perbaikan. Jelas kedua pengertian serupa karena pemeriksaan manajemen dilakukan saat manajemen beroperasi (Boynton, 2003).

$$
\text { Menurut Agoes (2012: }
$$

mendefinisikan:

"Audit Operasional adalah pemeriksaan terhadap kegiatan perusahaan, termasuk kebijakan akuntansi dan kebijakan operasional yang telah ditentukan tersebut sudah dilakukan secara efektif, efisien, dan ekonomis".

Dari definisi di atas maka diperoleh karakteristik audit operasional a) Audit operasional merupakan suatu proses yang sistematis seperti dalam audit laporan 
keuangan, audit operasional mencakup serangkaian langkah atau prosedur yang terstruktur dan terorganisasi. Aspek ini mencakup perencanaan yang tepat dan juga mendapatkan secara objektif, menilai bukti yang berkaitan dengan aktifitas yang diaudit. a) Penilaian operasi organisasi yang berdasarkan pada suatu kriteria yang ditetapkan atau disetujui. Dalam audit operasional, kriteria sering dinyatakan dalam standar kinerja (performance standars) yang ditetapkan industri. Audit operasional mengukur tingkat hubungan antara kinerja aktual dengan kriteria. b) Tujuan utama dari audit operasional adalah membantu manajemen dari organisasi yang diaudit untuk memperbaiki effectiveness, efficiency, dan economy dari suatu operasi. Dengan demikian, audit operasional memfokuskan prinsip pada masa yang akan datang. Ini berlawanan langsung dengan audit keuangan yang mempunyai fokus historis. c) Penerima yang tepat dari laporan audit operasional adalah manajemen atau individu yang meminta diadakannya audit. Kecuali jika diminta oleh pihak ketiga, pembagian laporan tetap dalam entitas. Dalam kebanyakan hal, dewan komisaris atau panitia audit menerima copy laporan audit operasional. d) Tidak seperti audit laporan keuangan, suatu audit operasional tidak berakhir dengan laporan atas temuan. Audit operasional memperluas dengan memberikan rekomendasi untuk perbaikan. Dalam kenyataannya mengembangkan rekomendasi merupakan salah satu aspek yang paling menantang dalam audit operasional.

Menurut Arens, Elder, Beasley,(2004) pada dasarnya audit operasional terbagi menjadi 3 jenis yaitu: fungsional,organisasi, penugasan khusus. Ketiga jenis audit operasional itu dapat di uraikan Fungsional Audit fungsional berkaitan dengan sebuah fungsi atau lebih dalam suatu operasional. Ini dapat berhubungan misalnya dengan fungsi penggajian suatu divisi atau untuk perusahaan secara keseluruhan. Keunggulan audit fungsional adalah memungkinkan adanya spesialisasi oleh auditor, kekurangan audit fungsional adalah tidak dievaluasinya fungsi yang saling berkaitan.

Tahapan dasar dalam melaksanakan audit operasional menurut Bayangkara (2008), yaitu: a) Audit pendahuluan dilakukan untuk mendapatkan informasi latar belakang terhadap objek yang diaudit, di samping juga dilakukan penelaahaan terhadap kebijakan berkaitan dengan aktifitas yang diaudit, serta menganalisis berbagai informasi yang telah diperoleh untuk mengidentifikasikan hal-hal yang potensial mengandung kelemahan pada perusahaan yang diaudit. b) Review dan pengujian pengendalian manajemen Pada tahapan ini auditor melakukan review dan pengujian terhadap pengendalian manajemen objek audit, dengan tujuan untuk menilai efektifitas pengendalian manajemen dalam mendukung pencapaian tujuan perusahaan. Hasil pengujian pengendalian manajemen ini dapat mendukung tujuan audit sementara menjadi tujuan audit yang sesungguhnya (definitive audit objective) atau mungkin ada beberapa tujuan audit sementara yang gugur. Karena tidak cukup bukti untuk mendukung tujuan audit tersebut. c) Audit terinci pada tahap ini auditor melakukan pengumpulan bukti yang cukup dan kompoten untuk mendukung tujuan audit yang telah ditentukan. Pada tahap ini dilakukan pengembangan temuan untuk mencari keterkaitan antara satu temuan dengan temuan yang lain dalam menguji permasalahan yang berkaitan dengan tujuan audit. Temuan yang cukup relevan, dan kompoten dalam tahap ini disajikan dalam suatu Kertas Kerja Audit (KKA) Untuk mendukung simpulan audit yang dibuat dan rekomendasi yang diberikan.

\section{Audit Atas Persediaan}

Pada setiap tingkat perusahaan baik perusahaan kecil, menengah, maupun peruasahaan besar. Persediaan sangat penting bagi kelangsungan hidup perusahaan. Perusahaan harus dapat memperkirakan jumlah persediaan yang dimilikinya, persediaan yang dimiliki oleh perusahaan tidak boleh terlalu banyak dan tidak boleh terlalu sedikit karna 
akan mempengaruhi biaya yang akan dikeluarkan untuk persediaan tersebut.

Persediaan merupakan suatu unsur umum yang memegang peranan penting dalam operasi perusahaan, yang secara kontinyu diperoleh atau diproduksi dan dijual mempunyai efek langsung terhadap laba perusahaan. Oleh karena itu para pemimpin perusahaan baik perusahaan dagang maupun industri selalu berusaha untuk mengelola persediaanya sebaik mungkin. Para ahli mendefinisikan persediaan bermacammacam sebagai berikut:

Menurut Prasetyo (2006:65) "persediaan adalah suatu aktiva yang meliputi barangbarang milik perusahaan dengan maksud untuk dijual dalam satu periode usaha yang normal, termasuk yang dalam pengerjaan/ proses produksi menunggu masa penggunaannya pada proses produksi".

Hendriksen (2001:570) menyatakan bahwa: Persediaan meliputi barang perdagangan yang dimaksudkan untuk dijual dalam kondisi usaha normal dan bahan baku serta dalam pembantu yang digunakan dalam proses produksi untuk dijual.

Pengertian persediaan menurut Kieso, Weiygand, Warfield, (2007:444), menyatakan bahwa:

“ persediaan adalah pos-pos aktiva yang dimiliki perusahaan untuk dijual dalam operasi bisnis normal atau barang yang akan digunakan atau dikonsumsi dalam memproduksi barang yang akan dijual.

Menurut Warren Reeve (2009:452).“ persediaan juga didefinisikan sebagai aktiva yang tersedia untuk dijual dalam kegiatan usaha normal dalam proses produksi atau penjualan dalam bentuk bahan atau perlengkapan (supplies) untuk digunakan dalam proses produksi atau pemberian jasa".

Menurut Stice dan Skousen (2009: 571). Persediaan adalah istilah yang diberikan untuk aktiva yang akan dijual dalam kegiatan normal perusahaan atau aktiva yang dimasukkan secara langsung atau tidak langsung ke dalam barang yang akan diproduksi dan kemudian dijual ".

\section{Ruang Lingkup Audit Operasional}

Ruang lingkup audit operasional lebih difokuskan pada fungsi produksi suatu perusahaan, yang berarti melakukan pemeriksaan segi operasional suatu perusahaan. Namun dalam hal ini suatu perusahaan mengalami keterbatasan dalam melaksanakan audit operasional tersebut. Keterbatasan yang terjadi dalam suatu perusahaan dalam melaksaan audit operasional antara lain: a) Waktu. Pemeriksa harus memberikan laporan kepada pihak manajemen sesegera mungkin agar masalah yang timbul dapat segera terselasaikan, sehingga menyebabkan terbatasnya waktu pemeriksaan. Untuk mengatasi keterbatasan waktu ini, audit operasional dapat dilakukan secara teratur untuk menghindari permasalahan agar tidak menjadi berlarut-larut. b) Keahlian kekurangannya pengetahuaan dan penguasaan berbagai disiplin ilmu dan bisnis merupakan salah satu keterbatasan. Tidak mungkin seorang pemeriksa dapat menjadi ahli dalam berbagai disiplin bisnis. c) Biaya yang dapat dihemat dari hasil pemeriksaan haruslah lebih besar dari biaya pemeriksaan itu sendiri.

\section{Efisiensi dan Efektivitas}

Audit operasional dikenal sebagai audit yang berkonsentrasi pada efektivitas dan efisiensi organisasi. Efektivitas mengukur seberapa berhasil suatu organisasi mencapai tujuan dan sasarannya. Efisiensi mengukur seberapa baik suatu entitas menggunakan sumberdaya dalam mencapai tujuannya. Sabagai contoh seorang auditor dapat memeriksa badan federal untuk menentukan apakah badan tersebut telah mencapai tujuannya seperti yang ditetapkan oleh "kongres" (efektivitas) dan menggunakan sumberdaya keuangannya secara benar (efisiensi). Pembahasan mengenai ekonomisasi, efisiensi dan efektivitas akan lebih mudah dipahami jika dibahas dalam kerangka inputproses-output. b) Efisiensi berhubungan dengan bagaimana perusahaan melakukan operasinya. Sehingga dicapai optimalisasi penggunaan sumberdaya yang dimiliki. Efisiensi berhubungan dengan metode kerja (operasi). 
Dalam hubungannya dengan konsep inputproses-output, efisiensi adalah rasio antara output dan input, Seberapa besar output yang dimiliki perusahaan. Metode kerja yang baik akan dapat memandu proses operasi berjalan dengan mengoptimalkan penggunaan sumberdaya yang dimiliki perusahaan. Jadi, efisiensi merupakan ukuran proses yang menghubungkan antara input dan output dalam operasional perusahaan (Bayangkara. 2008:13). Anthony (2005:174) berpendapat bahwa efisiensi adalah output terhadap input, atau jumlah output per unit input. Pusat tanggung jawab A lebih efisien dari pusat tanggung jawab B jika (1) menggunakan jumlah sumberdaya yang lebih sedikit namun memproduksi jumlah output yang sama atau (2) menggunakan jumlah sumberdaya yang sama namun memproduksi jumlah output yang lebih besar. b) Efektifitas bibandingkan dengan efisiensi, yang ditentukan oleh hubungan antara input dan output, efektiftas ditentukan oleh hubungan antara output yang dihasilkan oleh suatu pusat tanggung jawab dengan tujuannya. Semakin besar output yang dikontribusikan terhadap tujuan, maka semakin efektiflah tujuan tersebut. Efektifitas cenderung dinyatakan dalam istilahistilah subjektif dan nonalitis (Anthony,2005: 174). Efisiensi dan efektifitas berkaitan satu sama lain, setiap pusat tanggung jawab harus efektif dan efisien dimana organisasi harus mencapai tujuannya dengan cara yang optimal. Suatu pusat tanggung jawab yang dijalankan tugasnya dengan konsumsi terendah atas sumberdaya, mungkin akan efisien, tetapi jika output yang dihasilkan gagal dalam memberikan kontribusi yang memadai dalam pencapaian cita-cita organisasi, maka pusat tanggung jawab tersebut tidaklah efektif. (Anthony: 174-175).

\section{METODE}

Penelitian ini akan dilakukan pada usaha Depot Jaya Motor Kota Palopo di Jl.Tandipau No. 21.

Adapun jenis dan sumber data yang digunakan dalam penelitian ini adalah data kuantatif yaitu data yang diperoleh dari perusahaan dalam bentuk angka-angka. Sumber data yaitu: a) Data primer yaitu data yang bersumber dari hasil observasi dan kuesioner dari pimpinan serta karyawan Usaha Depot Jaya Motor kota Palopo. b) Data sekunder yaitu data yang diperoleh dari perusahaan dalam bentuk yang sudah jadi seperti : struktur organisasi, sejarah berdirinya perusahaan, laporan pembelian, persediaan, dan laporan penjualan.

\section{Populasi dan Sampel}

Populasi mengacu pada keseluruhan kelompok orang, kejadian,atau hal minat yang ingin peneliti investigasi. Sedangkan sampel adalah sekelompok atau bagian dari populasi. Dengan mempelajari sampel, peneliti akan mampu menarik kesimpulan yang dapat digeneralisasikan terhadap populasi penelitian (Uma Sekaran 2006:121-123).

Adapun yang menjadi populasi sekaligus sampel dalam penelitian ini adalah karyawan dari Usaha Depot Jaya Motor itu sendiri.

\section{Metode Pengumpulan Data}

Metode pengumpulan data yang dilakukan dalam penelitian ini adalah penelitian Lapangan (Field Research), yaitu penelitian yang dilakukan dengan mengunjungi secara langsung objek penelitian dengan cara: Observasi, wawancara, kuesioner,

\section{Uji validitas dan Reabilitas}

Sugiyono (2007:137) menjelaskan bahwa uji validitas merupakan alat ukur yang digunakan untuk mendapatkan data itu valid atau dapat digunakan untuk mengukur apa yang seharusnya diukur.

Uji validitas dilakukan dengan menggunakan teknik Pearson Correlation, yaitu dengan cara menghitung korelasi antara skor masing-masing butir pernyataan-pernyataan dengan skor total, jika korelasi antara skor masing-masing butir pernyataan dengan total skor mempunyai tingkat signifikansi di bawah 0,05 maka butir pernyataan tersebut dinyatakan valid dan sebaliknya (Ghozali,2009:49).

Uji reliabilitas dilakukan untuk menguji apakah jawaban dari responden konsisten atau stabil. Suatu angket dikatakan andal jika jawaban seseorang terhadap pertanyaan atau pernyataan adalah konsisten atau stabil dari 
waktu ke waktu. Suatu konstruk atau variabel dikatakan reliable atau andal jika memberikan nilai cronbach alpha $>0,6$ (Ghozali, 2005).

\section{Metode Analisis}

Bertitik tolak dari masalah dan hipotesis yang telah dikemukakan sebelumnya maka dalam membahas dan menganalisis permasalahan sekaligus membuktikan hipotesis maka penulis akan menggunakan metode Regresi Linear Sederhana, menurut Iqbal Hasan (2002:115) regresi linear sederhana adalah regresi linear dimana variabel yang terlibat didalamnya hanya dua, satu varibel terikat $Y$ dan satu variabel bebas $\mathrm{X}$ dan perangkat satu. Adapun rumus yang digunakan adalah sebagai berikut :

$\mathrm{Y}=\mathrm{a}+\mathrm{bX}+\mathrm{e}$

Keterangan :

$\mathrm{Y}=$ Kecukupan persediaan Barang Dagang

$\mathrm{X}=$ Audit operasional

$\mathrm{a}=$ intersep

$\mathrm{b}=$ Koefisien regresi

variabel X dan Y menggunakan Skala Likert, dimana indikator tersebut dijadikan sebagai titik tolak untuk menyusun item-item instrument yang dapat berupa pernyataan atau pertanyaan. Sakala Likert didesain untuk menelaah seberapa kuat subjek setuju atau tidak setuju dengan pernyataan pada skala 5 titik dengan respon terhadap sejumlah item yang berkaitan dengan konsep atau variabel tertentu kemudian disajikan kepada tiap responden (Uma Sekaran 2006:31).

Agar lebih mudah untuk melihat mengenai variabel penelitian yang dgunakan maka penulis menjabarkannya dalam bentuk operasionalisasi variabel yang dapat dilihat pada tabel berikut ini: 
Tabel .1 Operasional variabel X

\begin{tabular}{|c|c|c|c|c|}
\hline $\begin{array}{l}\mathrm{N} \\
\mathrm{O}\end{array}$ & Variabel & Definisi & Indikator & Skala \\
\hline 1 & $\begin{array}{c}\text { Audit } \\
\text { operasio } \\
\text { nal } \\
(\mathrm{X})\end{array}$ & $\begin{array}{l}\text { Audit } \\
\text { operasional } \\
\text { adalah } \\
\text { pemeriksaan } \\
\text { terhadap } \\
\text { kegiatan } \\
\text { perusahaan, } \\
\text { termasuk } \\
\text { kebijakan } \\
\text { akuntansi } \\
\text { dan } \\
\text { kebijakan } \\
\text { operasional } \\
\text { yang telah }\end{array}$ & $\begin{array}{ll}\text { - } & \text { Indepen } \\
\text { si audit } \\
\text { operasi } \\
\text { onal } \\
\text { - } & \text { Laporan } \\
\text { audit } \\
\text { - } \\
\text { Progra } \\
\text { m } \\
\text { kinerja } \\
\text { auditor } \\
\text { dan } \\
\text { Tindak } \\
\text { lanjut. }\end{array}$ & $\begin{array}{l}\text { Ordin } \\
\text { al }\end{array}$ \\
\hline
\end{tabular}

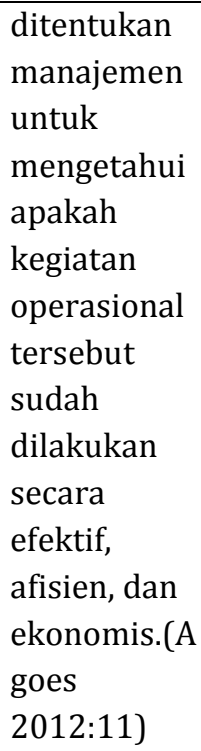

Tabel . 2 Operasional variabel Y

\begin{tabular}{|c|c|c|c|c|}
\hline No & Variabel & Definisi & Indikator & Skala \\
\hline 1 & $\begin{array}{c}\text { persediaan } \\
\text { barang dagang } \\
\text { (Y) }\end{array}$ & $\begin{array}{l}\text { Persediaan adalah suatu aktiva yang } \\
\text { meliputi barang-barang milik } \\
\text { perusahaan dengan maksud untuk } \\
\text { dijual dalam suatu periode usaha yang } \\
\text { normal, termasuk yang dalam } \\
\text { pengerjaan/proses produksi } \\
\text { menunggu masa penggunaannya pada } \\
\text { proses produksi (Prasetyo:65). }\end{array}$ & $\begin{array}{ll}\text { - } & \text { Efektifitas dan efisiensi } \\
& \text { operasi. } \\
\text { - } & \text { Keandalan data } \\
\text { persediaan. } \\
\text { - } \\
\text { Pemesanan dan } \\
\text { penerimaan barang. }\end{array}$ & Ordinal \\
\hline
\end{tabular}

Masing-masing variabel diatas diukur atas dasar tanggapan responden dan pernyataan

\section{Coefficients $^{\mathrm{a}}$}

\begin{tabular}{|cc|c|c|}
\hline \multirow{2}{*}{ Model } & \multicolumn{2}{|c|}{$\begin{array}{c}\text { Unstandardized } \\
\text { Coefficients }\end{array}$} \\
\cline { 3 - 4 } & B & Std. Error \\
\hline & (Constant) & 26.210 & 3.830 \\
1 & $\begin{array}{c}\text { Audit } \\
\text { Operasional }\end{array}$ & .473 & .086 \\
\hline
\end{tabular}

a. Dependent Variable: Kecukupan

Persediaan Barang Dagang

yang diberikan pada kuisioner yang diukur dengan menggunakan skala 5 tingkat (Likert) pengukuran yaitu

SS $\quad=$ Sangat setuju diberi skor 5

$\mathrm{S} \quad=$ Setuju, diberi skor 4

KS = Kurang Setuju, diberi skor 3
TS = Tidak Setuju, diberi skor 2

STS = Sangat Tidak Setuju, diberi skor 1

\section{HASIL DAN PEMBAHASAN}

\section{Uji Regresi Sederhana dan uji hipotesis}

Analisis regresi dilakukan untuk mengetahui pengaruh antara variabel independen dan variabel dependen. Dalam penelitian ini analisis yang digunakan adalah analisis regresi sederhana. Berikut adalah tabel dari hasil olahan SPSS V 21.0.

\section{Uji Regresi Linear Sederhana}

Dari tabel diatas dapat diperoleh rumus regresi linear sederhana sebagai berikut:

$$
\mathrm{Y}=26.210+0.473 \mathrm{X}+\mathrm{e}
$$

Arti dari persamaan regresi ini

Nilai konstanta (a) sebesar 26.210 artinya jika audit operasional nilainya adalah 0 , maka 
kecukupan persediaan barang dagang nilainya 26.210 .

Nilai Koefisien regresi variabel audit operasional adalah 0.473 , ini dapat diartikan bahwa setiap peningkatan audit operasional sebesar 1\% maka tingkat kecukupan persediaan barang dagang juga akan meningkat sebesar 0.473 atau $47.3 \%$.

\section{Uji t (T Test)}

Uji $\mathrm{t}$ digunakan untuk mengetahui apakah variabel independen berpengaruh signifikan atau tidak terhadap variabel dependen, dalam hal ini untuk mengetahui apakah variabel audit operasional berpengaruh secara signifikan atau tidak terhadap kecukupan persediaan barang dagang. Pengujian dilakukan menggunakan tingkat signifikansi 0,05 dengan derajat kebebasan $\mathrm{df}=\mathrm{n}-2$. Apabila nilai signifikan lebih kecil dari derajat kebebasan maka hipotesis alternatif diterima, yang menyatakan bahwa suatu variabel independen berpengaruh terhadap variabel dependen.

\section{Hasil Uji t}

Hasil dari uji $\mathrm{T}$ dengan membandingkan $t_{\text {hitung }}$ dan $t_{\text {tabel }}$ dimana $t_{\text {tabel }}(\mathrm{df}=\mathrm{n}-2$ atau 17-2=15), hasil diperoleh untuk t tabel sebesar 2,131 dan $t$ hitung sebesar 5.518 dengan tingkat signifikansi sebesar 0.000 .

Dimana nilai $t_{\text {hitung }}>t_{\text {tabel }}(5.518>2.131)$ dan dengan nilai signifikansi $<0,05(0.000<0,05)$ maka $\mathrm{H}_{0}$ ditolak dan $\mathrm{H}_{1}$ diterima, hal ini menunjukkan bahwa variabel audit operasional berpengaruh secara signifikan terhadap kecukupan persediaan barang dagang.

\section{Analisis Koefisien Korelasi dan Koefisien Determinasi $\left(\mathrm{R}^{2}\right)$}

Koefisien korelasi R menunjukkan seberapa besar korelasi atau hubungan antara variabel independen dengan variabel dependen. Koefisien korelasi dikatakan kuat apabila nilai $\mathrm{R}$
Coefficients ${ }^{\mathbf{a}}$

\begin{tabular}{|c|c|c|c|c|c|}
\hline \multirow[t]{2}{*}{ Model } & \multicolumn{2}{|c|}{$\begin{array}{l}\text { Unstandard } \\
\text { ized } \\
\text { Coefficients }\end{array}$} & $\begin{array}{l}\text { Standardi } \\
\text { zed } \\
\text { Coefficien }\end{array}$ & $\mathrm{t}$ & Sig \\
\hline & B & $\begin{array}{c}\text { Std. } \\
\text { Erro } \\
r\end{array}$ & Beta & & \\
\hline $\begin{array}{l}\text { (Consta } \\
\text { nt) } \\
1 \text { Audit } \\
\text { operasio } \\
\text { nal }\end{array}$ & $\begin{array}{l}26.2 \\
10 \\
.473\end{array}$ & $\begin{array}{c}3.83 \\
0 \\
.086\end{array}$ & .819 & $\begin{array}{l}6.8 \\
43 \\
5.5 \\
18\end{array}$ & $\begin{array}{c}.00 \\
0 \\
.00 \\
0\end{array}$ \\
\hline
\end{tabular}

a. Dependent Variable: kecukupan persediaan barang dagang

Sumber: Output SPSS, 21.0, 2015

berada di atas 0,5 dan mendekati 1. Dalam penelitian ini, nilai koefisien determinasi yang dipakai adalah Adjusted R Square. Adjusted R Square dianggap lebih baik dari $\mathrm{R}^{2}$ karena Adjusted R Square dapat naik atau turun apabila satu variabel independen ditambahkan ke dalam model regresi.

Tabel 3. Korelasi dan Koefisien Determinasi Model Summaryb

\begin{tabular}{|l|c|c|c|c|}
\hline Model & $\mathrm{R}$ & $\begin{array}{c}\mathrm{R} \\
\text { Square }\end{array}$ & $\begin{array}{c}\text { Adjusted } \\
\text { R Square }\end{array}$ & $\begin{array}{c}\text { Std. Error } \\
\text { of the } \\
\text { Estimate }\end{array}$ \\
\hline 1 & $.819^{\mathrm{a}}$ & .670 & .648 & 2.316 \\
\hline
\end{tabular}

a. Predictors: (Constant), Audit operasional b. Dependent Variable: Kecukupan persediaan barang dagang

Sumber: Output SPSS, 21.0, 2015

Dari tabel di atas dapat disimpulkan bahwa:

$\mathrm{R}$ dalam analisis regresi sederhana menunjukkan korelasi sederhana (korelasi person), yaitu korelasi antara satu variabel 
independen terhadap variabel dependen. Nilai koefisen korelasi (R) pada tabel diatas sebesar 0,819 artinya korelasi atau hubungan antara variabel audit operasional dengan variabel kecukupan persediaan barang dagang terjadi hubungan yang erat karena nilai koefisien korelasi diatas 0,5.

Pada tabel diatas menunjukkan bahwa nilai koefisien Adjusted R Square sebesar 0.648 atau $64.8 \%$. Maka dapat disimpulkan bahwa audit operasional memiliki pengaruh sebesar 64.8\% terhadap kecukupan persediaan barang dagang, sedangkan sisanya $35.2 \%$ dipengaruhi oleh variabel lain yang tidak dimasukkan dalam penelitian ini.

Standar eror of the Estimate, adalah ukuran kesalahan prediksi, nilainya sebesar 2.316. Artinya kesalahan dalam memprediksi kecukupan persediaan barang dagang sebesar $2.316 \%$.

\section{KESIMPULAN}

Tujuan dari penelitian ini yaitu untuk mengetahui apakah audit operasional berpengaruh secara signifikan terhadap kecukupan persediaan barang dagang.Berdasarkan pembahasan hasil penelitian, Audit operasional memiliki hubungan yang signifikan terhadap kecukupan persediaan barang dagang.hal ini dapat dilihat dari hasil pengujian thitung Audit Operasional sebesar 5.518 dan $t_{\text {tabel }}$ sebesar 2.131 ini menunjukkan bahwa nilai $t_{\text {hitung }}>t_{\text {tabel }}$ dengan tingkat signifikansi $0.000<0.05$. Dari nilai koefisien Adjusted R Square sebesar 0.648 atau 64.8\%. Maka dapat disimpulkan bahwa audit operasional memiliki pengaruh sebesar $64.8 \%$ terhadap kecukupan persediaan barang dagang, sedangkan sisanya $35.2 \%$ dipengaruhi oleh variabel lain yang tidak dimasukkan dalam penelitian ini.

\section{DAFTAR PUSTAKA}

Agoes, Sukrisno ,2012. “Auditing Pemeriksaan Akuntansi oleh Kantor Akuntan Publik", Jlid 1, cetakan ke-4, Lembaga Penerbit salemba Empat, Jakarta.

Anonimus,2007. PSAK No 14.

Arens, Alvin A. Rendal J Elder, Mark S Beasley, 2004. "Auditing and assurance Service: An Integreted Approach," Edisi ke-9. PT Indeks kelompok Gramedia, Jakarta.

,2006. " Auditing dan Pelayanan Verifikasi Pendekatan Terpadu," Edisi ke-9, Jilid 2, PT Indeks Kelomnpok Gramedia< Jakarta.

Bayangkara, IBK,2008. " Audit Manajemen, Prosedur dan Implementasi Management audit", Salemba Empat, Jakarta.

Boynton, Johnson, Kell,2003 . " Modern auditing, Edisi Ke-7 Jilid 2". Erlangga, Jakarta.

Ghozali,Imam, 2005. "Aplikasi Analisis Multivariate dengan Program Spss". Badan penerbit UNDIP,Semarang.

Guy M dan C Wayne, Alan J winters ,2003. "Auditing" Edisi Kelima, Erlangga, Jakarta.

Hakim, Lukman, 2003 . “ Peranan Sistem dan Prosedur Pencatatan Persediaan Barang pada Perusahaan dalam Melaksanakan Pengendalian Interen". Jurnal Arthavidya Vol 4, No 1.

Halim, Abdul, 2003 . “Auditing”,Edisi ketiga, unit penerbit dan percetakan akademi manajemen perusahaan YKPN, Jakarta.

$\begin{array}{ccc}\text { Harnato, } 2002 . \text {.Akuntansi } & \text { Keuangan } \\ \text { Menengah". } & \text { Cetakan } & \text { pertama, } \\ \text { penerbit BPFE UGM, yokyakarta. }\end{array}$


Hendriksen,E,S, Breda, M,F ,2001 . "accounting theory" Rivard D Irwin inc, Boston.

Iriyadi, 2004. “ Evaluasi Atas Prosedur Pemeriksaan Oprasional dalam Meningkatkan Efektivitas Pengendalian Intern Penjualan". Jurnal Ilmiah ranggading,Vol 4, No 1. Hlm 1520.

Iqbal Hasan, 2002. "Pokok-Pokok Materi Metodologi Penelitian dan Aplikasinya". Penerbit Ghalia Indonesia, Jakarta.

Kieso, Waygand Warfield, 2007. "Akuntansi intermediate jilid 1". Erlangga, Jakarta.

Mudricah, 2008 . "sistem Akuntansi Persediaan Bahan Baku Pada PT SINAR LENDOH TERANG AMBARAWA". Skripsi, Universitas Negeri Semarang.

Mulyadi, 2002. " Auditing”. Edisi ke-6, Jilid 1, Salemba Empat, Jakarta.

Prasetyo, 2006. " Pengembangan Modal Persediaan dengan Mempertimbangkan Waktu Kadaluarssa dan Faktor Unit Diskon, Jurnal Ilmiah Teknik Industri, volume 4, No 3, Universitas Muhammadiyah, Surakarta.

Purwono, Edi, 2004. "Aspek-aspek EDP Audit Pengenalan Intern pada Komputerisasi", ANDI, Yogyakarta.

Setiyawan, Agus, 2007. "Pengaruh Sistem Pengendalian Intern dan Pengelolaan Persediaan Terhadap Audit Operasional pada PT PERTAMINA PERSERO". Skripsi, Universitas Islam Negeri Syarif Hidayatullah, Jakarta.

Stice dan Skousen, 2009. "Akuntansi Intermedite". Edisi keenambelas, buku 1, Salemba Empat, Jakarta.
Sugiyono,2009. "Metode Penelitian Kuantitatif dan Kualitatif", penerbit Alfabeta,Cv, Bandung.

Tunggal,Ak,MBA, 2008 . Audit Manajemen Konteporer.Penerbit Harvarindo. Jakarta Barat.

Uma Sekaran, 2006. "Metodologi Penelitian Untuk Bisnis". Buku 2,Penerbit Salemba Empat,Jakarta.

2009. "Metodologi Penelitian Untuk Bisnis". Buku 1,Penerbit Salemba Empat,Jakarta.

Warren S carl, James M, Reeve dan Philip E. Fees,2009 . "Pengantar Akuntansi". Edisi 21, salemba empat, Jakarta. 